\title{
REVIEW ESSAY: DEATH AND DELUSION ON THE TRADE FRONT
}

\section{How to Kill a Country: Australia's Devastating Trade Deal with the United States}

Linda Weiss, Elizabeth Thurbon and John Matthews (Allen and Unwin, Sydney, 2004, 204 pp, \$22.95, ISBN 1741145856)

\section{All the Way with the USA: Australia, the US and Free Trade \\ Ann Capling (UNSW Press, Sydney, 2004, 96 pp, \$16.95, ISBN 0868409766)}

There are three major elements to trade policy in today's world - the first is the expansion of trade through multilateral liberalisation under the auspices of the World Trade Organisation (WTO), the second is the movement towards regional trade agreements (RTAs), and the third is the development of bilateral deals. Under the Howard government, Australian trade policy has shifted unequivocally from multilateralism and (open) regionalism towards bilateralism. Australia now has bilateral deals with New Zealand, Singapore, Thailand, and of course the United States. It also has a series of scoping studies, partnerships and negotiations going on with ASEAN, Malaysia, Japan and China.

Trade policy took center stage in 2004 with the debate over the Australia-US Free Trade Agreement (AUSFTA). The shift towards bilateral deals, especially with the US, has attracted criticism across the political spectrum. Many liberal supporters of freer trade are critical of the shift towards bilateralism because it is seen to damage the first best option of multilateral liberalisation. But criticism has also come from the left. Critics of Coalition trade policy, including the authors of the two books under review, argue that the free trade deal restricts Australia's ability to make health and social policy, damages the progress of the WTO and makes Australia's trade relationships confusing. Most importantly, however, critics of AUSFTA argue that it is simply a bad deal that should have been rejected. Liberal detractors point out that the deal is anything but a 
free trade agreement, but liberal supporters argue that this is beside the point: what matters is the expansion of trade and investment and connecting Australia more closely with the world's largest economy. Supporters also point out the potential economic gains (although these vary considerably), the benefits to consumers of any decline in protectionism, and the potential increase in foreign investment.

Given this context the AUSFTA provides excellent fodder for research and analysis of Australian political economy in general and trade policy in particular. It shows the continuing impact of political considerations on what were often erroneously thought of as economic processes. The two importantbooks under review by Ann Capling, All the Way with the USA and Linda Weiss, Elizabeth Thurbon and John Matthews, How to Kill a Country: Australia's Devastating Trade Deal with the United States provide extensive critiques of AUSFTA and the shift in Australian trade policy towards bilateralism. They can be read to balance the government's extensive support of the deal that can be found on the Department of Foreign Affairs website.

Both books are very short. Capling's is only 96 pages including notes and Weiss et al.'s is only 190 pages. Both are also accessible to the non-specialist reader, but it is evident that they were both written in considerable haste to be released at the most opportune time for sales.

\section{How to Kill a Country: Australia's Devastating Trade Deal with the United States}

The major contention of Weiss et al. is that when analysing AUSFTA, we should not focus on wins or losses for particular sectors of the economy, but on 'the dramatic undoing of Australian institutions under the FTA, and the inevitable loss of

prosperity and sense of 'who we are' that this will entail' (p. 5; see also p. 19). 
Heady stuff indeed. Given the extreme title of the book, the argument needed to be made that the problems went beyond market access issues, because, as important as they may be, they do not determine the survival of a country. The authors' concern about institutional change fits well within the wider concern of many on the left about the more general impact of economic globalisation on distinctive national institutions.

Their arguments are also relevant to contentions about the continuing role of the state in today's globalising world: contrary to assertions that globalisation restricts policy choices, many of the changes supposedly forced on states by the global economy are instead political choices and, often, stupid ones at that. It is evident that the authors believe that this particular political choice falls into the latter category. Contrary to this view, proponents of the deal often resorted to the argument sine qua non of globalisation: there is no alternative (TINA). In this case, TINA manifested itself in the proposition that in a globalising world economy, Australia could notafford to bypass the opportunity to tie itself up with the world's largest economy. On balance, however, the argument that AUSFTA imposes a "death sentence for Australia as an independent country" (p. 3) struck me as a little overdone. They also overestimate Australia's importance in the global scheme of things, as evidenced by the following quote: "Once this FTA is implemented, then the era of the American Economic Empire may be said to have begun, with Australia as one of the first 'developed' countries in tow" (pp. 223). Unfortunately, Australia is just not that important to America's development of its 'economic empire'.

The book is divided into six chapters or, as they suggest, six steps to kill a country. Step one involves proposing a deal with a partner that has a history of generating lopsided trade deals. Step two entails destroying the competitiveness of Australian agriculture 
by undermining quarantine. Step three requires undermining the effective and equitable Pharmaceuticals Benefit Scheme. Step four involves abandoning industry promotion through public purchasing policy. Step five entails replacing Australia's intellectual property regime and cultural production with that of the US. Finally, step six necessitates doing whatever it takes to stifle opposition to the bill.

Weisset al. briefly outline the outcomes in terms of agriculture (pitiful) and manufacturing (overblown) and pillory the arguments of those like Alan Oxley who argue that the real gains are in investment. They provide a table of woe on page 7 to suggest that there really are very few gains for Australian producers. But they spend very little time analysing these market outcomes and over the next four chapters the reader is provided with a frightening account of the potential damage that AUSFTA could do to Australia's economy and society. Australia has long been accused of using quarantine to protect Australia agriculture and, in recent years, Australian producers have lost some significant battles at the WTO. Just where the balance should lie in this debate is a difficult one fornon-scientists and, indeed, even for scientists as one group of experts pits its scientific knowledge against another. There is no doubt, however, for Weiss et al. with the chapter (or Step 2) subtitled: “Open Season for Pests and Diseases" (p. 28). Undoubtedly the potential for damage to Australia's clean island image is of considerable concern. The authors contend that while AUSFTA does not "formally circumvent the WTO's dispute settlement procedures" they "preempt those disputes from arising in the first place" (p.55).

Step three concerns what the authors argue will be the undermining of "a world renowned institution that delivers affordable medicines to those most in need" (p.58). This they argue "will not only reduce a once proud healthcare institution to a pawn of 
multinational pharmaceutical companies, but will also push up the price of drugs, placing them out of reach for many ... citizens" (ibid). Most Australians would be particularly concerned about this and indeed Latham acted to exploit this concern. The government's response to these accusations was to argue that they were scaremongering. Undoubtedly US pharmaceutical companies are opposed to the PBS and it is probably not controversial to argue that equity is not their greatest concern. Despite public apathy, it would be a brave government that would allow the PBS to be obviously undermined by US companies in practice rather than theory. The PBS is a very effective institution that is almost universally supported.

The authors argue that the deal will "refashion the priorities of the PBS, create new processes "to review unfavourable PBS decisions", develop the Medicines Working Group to establish dialogue between Australia and the US, delete social and cost concerns, quash generic competition, and, finally, put the "PBS into a trade sanctions and legal sanctions context" (pp.63-68). They also outline a series of myths associated with US pharmaceuticalcompanies (pp.70-6). Some of the evidence they present is chilling and suggestive of the possibility that the pursuit of self interest by individuals and companies may not always have the associated benefits for society that economic liberals from Adam Smith onwards have implied. Australia, the authors assert, faces a "death sentence for sensibly priced medicines" (p. 81). But they go further, asking whether the Howard Government is acting as an agent for the international pharmaceutical industry.

The abandonment of attempts to use government procurement as a tool of industry development constitutes the fourth step in the death of a country. In the agreement, Australian firms will have access to the US government procurement 
market for the first time but the authors suggest that this will be highly qualified by “Buy American" norms (p. 89). For US firms, the agreement removes performance indicators such as local content and offset provisions. It also outlaws buy national or local preference provisions. Both countries, however, do retain small business exemptions. A small firm in the US is defined as one with up to 1500 employees, while for Australia it is 200 . The deal also threatens to increase uncertainty, costs and legal interference (pp. 93-4). Overall, the authors' contention is that the US utilises a range of strategies to support industry whilst Australia, rather foolishly, has removed restrictions and requirements on US companies. Given Weiss's support for East Asian style industry policies, it is not surprising that the chapter concludes that:

The most damaging implications of the FTA's government procurement Chapter, however, is that it effectively cuts off our lifeline to procurementlinked industrial renewal and nation-building in the future. In other words, our ability to return to industry policies in the future is circumscribed by AUSFTA. (p.112)

The penultimate step in Australia's murder by agreement involves the supplanting of Australia's already internationally compliant intellectual property (IP) regime with that of the US. Weiss et al. argue that these rather esoteric issues affect each and every Australia. The most important impacts, however, are on Australia's innovative industries and the balance of power(p.114). Given the importance of the IP sector for the US economy, it is perhaps not surprising that the dominant concern of the US is the "rights of IP holders (the majority of whom happen to be large American corporations)" (p. 115). Such measures, as the authors correctly point out, have nothing to do with free trade, indeed, quite the opposite (p. 116). In this very comprehensive chapter, the authors argue that the FTA will subject Australians to US law, ruin our generics industries, increase royalty payments to the US and undermine 
innovation in Australia's biotechnology and ICT sectors.

The final chapter (or Step six) attempts to make sense of why the Howard government would sign a deal that the authors have effectively shown is against Australia's national interest. They point out that the two previous offers by the US for a trade deal were unequivocally rejected. To understand the shift, they suggest one has to go back to the failed WTO meeting in Seattle. This failure occurred within an already existing predilection of the Howard government for bilateralism. Together these two factors gained greater salience after the terrorist attacks of September 2001. They quote Trade Minister Mark Vaile who suggested that AUSFTAwould "put our economic relations on the same mature footing as our political and security relations" ( $p$. 141). Weiss et al. rightly point out that there was considerable (misguided) faith in an economic dividend from our support for US policy in the Middle East. While it is not surprising that Australia did not get a good deal out of the US, it is surprising that the government agreed to sign. The problem for the government, the authors suggest, was how to sell such a lame deal. They argue that the government's response was to bribe the sugar industry and to offer inducements to other industries with few gains from the deal.

\section{All the Way with the USA: Australia, the US and Free Trade}

Ann Capling tells a more moderate story of 'trade policy lost' under the Howard government. Her major criticism is of the shift to bilateralism that AUSFTA represents and the downgrading of the flawed but beneficial multilateral regime of the General Agreement on Tariffs and Trade and the World Trade Organisation. Capling refuses to call such trade deals free trade agreements referring to them, as the WTO prefers, as preferential trade agreements (PTAs). For a more comprehensive 
treatment of Australian trade policy, the reader is directed to Capling'sexcellent, earlier full-length book: Australia and the Global TradeSystem.1

AUSFTA, Capling argues, represents "a historic departure for Australia" (p. 8). This departure involves the shift from Australia's commitment to non- discrimination in trade relations and the abandonment of the practice of keeping trade and security concerns separate. The deal, Capling contends, also has considerable effect on domestic policyand regulation and should be seen "in the context of contemporary debates about globalisation and the impact of international commitments on domestic policy-making, and concerns about the lack of opportunities for public participation in these processes" (pp. 9-10).

Disagreeing with the 'death of a country' theme of Weisset al., Capling does, nevertheless, argue that AUSFTArepresent something important:

Is the Australia-US trade agreement really a disaster, as suggested by Greens leader Bob Brown? Perhaps not, but it does raise a number of fundamental questions about trade policy, and in particular the way in which our trade policy reflects and shapes our common values, our economic relations, our capacity to make a difference in multilateral institutions, and our future policy choices. (p. 10)

Chapter one makes a briefbut eloquent case for multilateralism and offers a critique of the Howard government's shift to bilateralism. She contends that multilateralism and bilateralism in trade, contrary to the government's arguments, cannot coexist and that 'bilateralism has not served Australia's trade interests well' (p. 15). The negative effects she outlines include the impact on East Asian views of Australia (something that the Howard government argues has been refuted by our (eventual) invitation to the East Asian Summit). Most significant, however, is the fact 
that bilateralism has undermined our support for and focus on multilateralism. It is multilateralism that generates the most benefits for small, relatively powerless countries like Australia.

Chapter two discusses the decline of the WTO in the face of more than 300 regional trade agreements (80 per cent of which are bilaterals) (p. 29). The major factor in this decline, she suggests, is the declining enthusiasm of the US for multilateralism. The consequences of this undermining of multilateralism are severe: an increase in existing inequalities "between rich and poor" (p. 37). The implications for Australia are also dire (pp. 37-8). Capling maintains that Australia cannot benefit from a broken down multilateral system that returns unequivocally to discrimination.

Chapter three begins by outlining the state of play of US-Australia trade: "Among US export markets, Australia ranks fifteenth ... Australia is even less significant as a source of imports ... ranking 29th in importance and accounting for a mere 0.5 per cent of the US import market" (p. 39). This unequal trade relationship has been made worse by US import restrictions. Noting the decision to reject previous advances for a trade deal, Capling says that the change in Australia's view on an agreement with the US has to be seen within the context of Howard's "new bilateralism" (p. 40) and concerns about developments in the East Asian region (pp. 44-9). She outlines the trend towards PTAs in the region attributing their growth to their political advantages and the decline of APEC: Australia is not "being excluded from Asia by dint of preferentialtrade agreements" (p.47). Also important is the fact that the Howard government was keen in the early part of this decade to re-establish better ties with the US after the acrimony associated with the Howe Leather and lamb trade disputes and the disagreements over East Timor. But perhaps most significant is the changed 
international environment after September 11, 2001: "Since the beginning of the 'war on terror', both governments have framed the quest for a trade agreement in the context of strengthening the Australia-US alliance more generally" (p. 53). Capling questions what she suggests is the subordination of Australia's economic interests to strategic ones.

The title of chapter four - "Adeal at any cost" - gives a flavour of Capling's view of the agreement. She begins with the sobering fact that the Australian negotiators recommended rejecting the deal and outlines the government's determination to sign even though last minute pleas to the US for a better deal were rejected by the Bush administration. Although against the agreement, Capling is circumspect about its costs: "it is impossible to predict with any certainty the potential costs and benefits of the agreement" (p. 58). Reflecting similar concerns to Weiss et al. she states: "For many Australians, though, the benefits to the business community are dwarfed by the costs of the agreement to Australia's social programs, to its capacity to regulate in areas such as culture and health, and to its sovereignty more generally." (p. 59)

Maintaining the theme of death, Capling argues that the deal represents the death of trade policy" in Australia (p. 77). This seems a confusing statement, however, equating trade policy to multilateralism. The Howard government has a definite trade policy, it just isn't one with which Capling agrees. She highlights the government's neglect of the Cairns group as indicative of its lack of concern for the gains that could be made for Australia in WTO negotiations. Australia, she opines, has "taken its eyes off the main game" (p. 80) and has lost its status as the "champion of fair trade in agriculture" (p. 82). But most important is the fact that: 
Australia no longer has a trade policy to speak of, and there is considerable evidence that Australia's ability to compete in global markets has actually declined under the Howard government ... [Since 1997,] Australia has been sucking in imports at three times the rate of its export growth. (p. 84)

Perhaps what she is alluding to here is that the Australian government does not have an effective industry policy that could help to improve Australia's trade balance.

\section{Conclusion}

Weiss, Thurbon and Matthews declare "the days of being the 'lucky country' - even with the phrase's ironic overtones - are over" (p. vi). The view that the deal "changes everything" is, however, outdated and misplaced. It is not this latest instalment of policy that has changed everything, rather it is the fundamental shift in Australian political economy begun in 1983 with the liberalisation of the Australian with the liberalisation of the Australian financial system and continued throughout the 1980 s and 1990s by both Labor and Coalition governments. For many, the luck continues. Fourteen years of growth has produced a considerable amount of wealth for many Australians and the economy has expanded by close to 60 per cent during this time. Opponents of neo-liberal globalisation have to face up to the fact that these changes have produced the goods for a majority of Australians (at least up to this point)! For many others, however, the luck ran out quite some time ago. In sum, then, the willingness of the government to sign this deal is indicative rather than substantive. Although it does not necessarily fit neatly into the neo-liberal globalising framework, it does fit the general direction of the Howard government, especially its lack of concern about public health and a distinctively Australian cultural industry (don't they all vote Labor anyway?). What matters more for the agenda that the authors of these books would 
probably prefer is for a government like Howard's not being elected four times, with the last one giving them power unseen in Australia since the early 1980s.

Of the two books, Capling's account is more balanced and sets AUSFTAwithin the wider context of Australian trade policy. The problem with Weiss, Thurbon and Matthews' account is that its overstatement sullies the book's important message that the deal is a bad one. On the other hand, given the level of uncritical support for the trade deal in much of the media and from government sources it may be of some value to have a book like this one. Although the agreement might not be as damaging as the title of Weiss, Thurbon and Matthews' book suggests, the question remains as to why the government signed such a poor deal? The answer to this question is probably the same as the answer to the question as to why the government went to war in Iraq. The Howard government has decided that the longer-term strategic benefits of being very closely tied to the US make thesetwo seemingly poor decisions beneficial for Australia in the longer-term.

Tom Conley Griffith University 